УДК 374.7 (450)

DOI: $\underline{10.35619 / \text { iiu.v2i13.357 }}$

Кристопчук Тетяна доктор педагогічних наук, доцент, професор кафедри теорії і методики виховання Рівненського державного гуманітарного університету, м. Рівне, Україна ORCID: 0000-0002-0104-9901 e-mail: krystopchuk@ukr.net

\title{
ОСВІТА ДОРОСЛИХ У КОНТЕКСТІ СУЧАСНОЇ НЕПЕРЕРВНОЇ ОСВІТИ В ІТАЛІЙСЬКІЙ РЕСПУБЛІЦІ: НАВЧАННЯ ТА ВИХОВАННЯ
}

Анотація. У статті проаналізовано вихідні концептуальні положення щодо розвитку освіти дорослих, відображені в законодавчо-нормативній базі Італійської Республіки. Охарактеризовано освіту дорослих як сукупність навчально-виховних процесів формальної, неформальної освіти та інформального навчання.

Виокремлено основні компоненти змісту освіти дорослих у контексті сучасної неперервної освіти. Визначено форми реалізації освіти дорослих. Зазначено, що навчання дорослих організовується у постійних територіальних центрах (СТР) та вечірніх курсах, що проводяться закладами вищої освіти. Акцентовано, що розвитку освіти дорослих сприяють обласні центри освіти дорослих (CPIA) та регіональні центри досліджень, експериментів та розвитку (CRRS\&S). Визначено структуру обласних центрів освіти дорослих (CPIA).

Наголошено, що освіта дорослих охоплює освіту осіб, які перебувають у місцях позбавлення волі та профілактичних установах. Організація освітньо-виховного процесу у таких закладах розглядається як комплексна допомога ув'язненим та звільненим особам щодо визначення особистого плану життя та формування власної відповідальності, сприяє їхній реінтеграції у суспільство та відновлення їхнього соціального статусу повноцінного члена суспільства.

Ключові слова: освіта дорослих; законодавче регулювання освіти дорослих; зміст освіти дорослих; форми реалізації освіти дорослих; обласні центри навчання дорослих; регіональні центри досліджень, експериментів та розвитку.

Постановка проблеми. У «Меморандумі безперервної освіти Європейського Союзу» (Ліссабон, 2000) визначено три види освітньої діяльності: «формальна освіта, результатом якої $\epsilon$ отримання загальновизнаного диплома чи атестата; неформальна освіта, що, зазвичай, не передбачає отримання документа, здійснюється в освітніх 


\section{Інноватика у вихованні. Випуск 13.Том 2. 2021.}

закладах або громадських організаціях, клубах, гуртках, а також під час індивідуальних занять з репетитором або тренером; інформальне навчання - індивідуальна пізнавальна діяльність, що супроводжує щоденне життя і не обов'язково має цілеспрямований характер. Континуум неперервної освіти робить неформальну освіту та інформальне навчання рівноправними учасниками процесу навчання» (European Communities: A Memorandum, 2000).

Освіта дорослих тлумачиться як сукупність навчальних процесів формальної, неформальної освіти та інформального навчання, за допомогою яких люди, які в суспільстві вважаються дорослими, розвивають здібності, збагачують знання та підвищують свою технічну чи професійну кваліфікацію, розвиваються та покращують свою здатність до життя та праці як у власних інтересах, так і в інтересах громади й суспільства.

Мета освіти дорослих - створення можливостей для дорослих людей набути навичок реалізації своїх прав, сприяти професійному розвитку та економічному зростанню, розширити можливості у працевлаштуванні.

Ключові сфери освіти дорослих визначено у Рекомендаціях ЮНЕСКО (Recommendation on adult learning and education, 2015): «базові навички та грамотність; безперервна освіта та професійне зростання; загальнодоступна й громадянська освіта, формування навичок активної громадянської позиції».

Аналіз останніх досліджень 3 проблеми. Важливими для дослідження є праці вітчизняних вчених щодо видів освітньої діяльності у системі сучасної неперервної освіти дорослих (формальної, неформальної, інформальної). Зокрема, проблеми розвитку неформальної освіти дорослих висвітлено у працях вітчизняних науковців, а саме: «Підходи до визнання результатів неформальної та інформальної освіти дорослих у Скандинавських країнах» (О. Огієнко); «Неформальна освіта дорослих у країнах ЄС» (А. Гончарук); «Неформальна освіта дорослих у навчальних гуртках Швеції» (В. Давидова). Сучасні тенденції розвитку неформальної освіти дорослих в Німеччині стали предметом дослідження О. Шапочкіної.

Мета статті - проаналізувати нормативно-правове забезпечення освіти дорослих у контексті концепції неперервної освіти в Італійській Республіці; схарактеризувати освіту дорослих як сукупність навчальновиховних процесів формальної, неформальної освіти та інформального навчання.

Виклад основного матеріалу дослідження. Система освіти для дорослих існує в Італії з 1997 року та охоплює види діяльності, спрямовані на збагачення культури, перепідготовку та професійну мобільність дорослих. Освіта дорослих реалізується через співпрацю школи та місцевих громад із залученням основних соціальних партнерів, що діють на певній території. 


\section{Інноватика у вихованні. Випуск 13.Том 2. 2021.}

Вихідні концептуальні положення щодо розвитку системи освіти дорослих в Італії відображено в законодавчо-нормативній базі, зокрема, у таких документах, як (Indire, 2021): Постанова міністрів, № 455/1997 (Створення постійних територіальних центрів); Закон про фінанси 2007 р., ст. 1, п. 632; Указ міністра від 25 жовтня 2007 р. (Реорганізація постійних територіальних центрів для освіти дорослих та вечірніх курсів); Закон від 28 червня 2012 р., п. 92 (Реформа ринку праці з метою зростання); Указ Президента Республіки від 29 жовтня 2012 р., п. 263 (Загальні правила переосмислення дидактичної організації центрів освіти дорослих, включаючи вечірні курси); Законодавчий декрет №13/2013 (Визначення загальних правил та основних рівнів ефективності для ідентифікації та підтвердження неформальної освіти та інформального навчання, а також мінімальних стандартів обслуговування національної системи сертифікації навичок); Міжвідомчий указ від 12 березня 2015 p. (Рекомендації щодо переходу до нової системи. План заходів щодо інновацій в галузі освіти дорослих); Міжвідомчий указ від 30 червня 2015 p. (Визначення операційної бази для національного визнання регіональних кваліфікацій та загальних компетенцій в межах Національного довідника освітніх, навчальних кваліфікацій та професійних кваліфікацій); Міжвідомчий указ від 8 січня 2018 р. (Встановлення національної рамки кваліфікацій відповідно до Національної системи сертифікації навичок).

У Законі Італійської Республіки «Про реформу ринку праці» навчання впродовж життя розглядається як «будь-яка діяльність, яка здійснюється людьми формально, неформально, інформально на різних етапах життя 3 метою вдосконалення знань, навичок та компетенцій 3 особистої, громадянської, соціальної та професійної точки зору» (Закон 92 від 28.06.2012 (з правками від 30.12.2020), стаття 4, пункт 51) (Legge 92, 2012).

T. Сімкінс (T. Simkins, 1977, с.53) проаналізував програми формальної та неформальної освіти, виходячи з таких характеристик, як «цілі, тривалість, зміст, місце, ресурсозатратність, контроль». Формальна освіта дорослих характеризується тривалістю в часі та отриманням офіційно визнаних документів про освіту, в той час як неформальна освіта не передбачає отримання таких документів і $є$ короткочасною. За змістом формальна освіта - стандартизована, орієнтована на основні положення навчального матеріалу, неформальна - індивідуалізована, орієнтована на результат. Заклади формальної освіти не орієнтуються на близькість розташування від місця проживання, а заклади неформальної освіти орієнтовані на близькість від місця проживання. Контроль у закладах формальної освіти зовнішній (ієрархічний), у неформальної - це самоврядування або демократичний стиль.

Відповідно до реформ, проведених в Італії впродовж 2007-2016 pp., Міністерством освіти, університетів та досліджень спільно 3 Міністерством економіки і фінансів було реструктуризовано систему освіти дорослих. Навчання дорослих організовувалося у постійних 
територіальних центрах (Centri Territoriali permanenti - CTP) та вечірніх курсах, що проводилися закладами вищої освіти (Ministero dell'Istruzione, 2021).

Відповідно до мети реформи було створено обласні центри навчання дорослих, які одержали організаційну й навчально-методичну автономію та можливість навчати такі категорії дорослих, що не закінчили обов'язкову середню освіту й бажають отримати атестат про закінчення та першого ступеня середньої школи; прагнуть отримати атестат про закінчення другого ступеня середньої школи; дорослі іноземці, що хочуть записатися на курси італійської мови як іноземної; молодь у віці 16 років і старші, які мають атестат випускника початкової й молодшої середньої школи, але не мають можливості відвідувати денні курси.

Серед стратегічних інфраструктур для впровадження системи навчання впродовж життя основну роль відіграють територіальні мережі навчання впродовж життя (RETAP).

У Резолюції Європейської Ради 2011 / с 372/01, опублікованої в GUCE від 20 грудня 2011 р., щодо навчання дорослих зазначається, що «навчання дорослих $є$ важливим елементом циклу навчання упродовж усього життя, що охоплює весь спектр формальних, неформальних та інформальних навчальних заходів як загальних, так і професійних, що здійснюються дорослими після виходу 3 навчального циклу та початкового навчання» (Risoluzione del Consiglio Europeo, 2011, c.9).

B Італії створено міжінституційні відділи 3 питань навчання впродовж життя, які подають пропозиції стосовно визначення мінімальних стандартів та стратегічних напрямів розвитку навчання впродовж усього життя та організації територіальних мереж.

3 метою реалізації програми навчання впродовж життя Генеральним директоратом шкільних систем та оцінки національної системи освіти впроваджено Національний план гарантування кваліфікації для дорослого населення відповідно до Рекомендації Ради від 19 грудня 2016 року «Шляхи підвищення рівня кваліфікації: нові можливості для дорослих» (Ministero dell'Istruzione, 2021).

Розвитку освіти дорослих сприяють СРІА (Centri provinciali per l'istruzione degli adulti) - Обласні центри освіти дорослих, створені указом Президента Італійської Республіки від 29 жовтня 2012 року. Вони являють собою тип автономного навчального закладу зі своїм персоналом та специфічною дидактичною та організаційною структурою. Робота таких центрів реалізується в напрямах: шляхи розвитку освіти дорослих; ініціативи з розширення освітньої пропозиції; дослідження, експерименти та розвиток у галузі освіти дорослих.

Обласні центри освіти дорослих поділяються на «територіальні мережі послуг», структуруються за трьома рівнями: Рівень А: адміністративна одиниця; Рівень В: Дидактична одиниця; Рівень С: Навчальний підрозділ. 


\section{Інноватика у вихованні. Випуск 13.Том 2. 2021.}

3 адміністративної точки зору (рівень А) CРIA поділяються на центральний офіс та пункти навчання першого рівня (пов'язані з ними офіси), де проводяться курси першого рівня та курси грамотності, а також курси вивчення італійської мови. Такі пункти розподілу першого рівня визначаються регіонами.

CPIA, з організаційно-дидактичної точки зору (рівень В), належать до закладів середньої школи, які проводять курси освіти дорослих другого рівня. Ці пункти другого рівня облаштовані в загальноосвітніх навчальних закладах другого ступеня та визначаються регіонами.

Обласні центри освіти дорослих як адміністративна одиниця укладають конкретні угоди (відповідно до статті 7 Указу Президента Республіки 275, 1999р.) із навчальними закладами щодо визначення критеріїв та методів загального організаційно-дидактичного планування курсів другого рівня; створення та функціонування Комісії для визначення індивідуальної угоди про навчання; впровадження специфічних системних заходів, що мають сприяти відповідним зв'язкам між освітніми ланками першого та другого рівнів, використовуючи новітні технології.

Обласні центри освіти дорослих (рівень С) можуть розширити пропозицію щодо навчання дорослих шляхом укладання угод з місцевими органами влади та іншими державними та приватними структурами, особливо з посиланням на навчальні структури, акредитовані регіонами. Це ініціативи щодо зміцнення навичок громадянської позиції, а отже, можливості працевлаштування населення.

Регіональні центри досліджень, експериментів та розвитку (Centri Regionali di Ricerca, Sperimentazione e Sviluppo (CRRS \& S)). Згідно статті 6 указу Президента Республіки 275 від 8 березня 1999 р. СРIА як автономні навчальні заклади проводять наукові дослідження, експерименти та розробку (RS\&S) у галузі освіти дорослих. Генеральний директорат 3 питань освіти та оцінки національної системи освіти створив Регіональний центр досліджень, експериментів та розвитку (CRRS \& S) у галузі освіти дорослих в рамках CPIA в кожному регіоні. Кожний CRRS \& $\mathrm{S}$ координується технічно-науковим комітетом, в якому беруть участь представники регіональних закладів шкільної освіти та університетів.

Починаючи $з$ 2016/2017 навчального року, Міністерство освіти, університетів та досліджень підтримує розвиток Регіонального центру досліджень, експериментів та розробок (CRRS \& S), очолюваного CPIA, у співпраціз іншими СРIA відповідного регіону (Ministero dell'Istruzione, 2021).

Кожен CPIA-CRRS \& S координується технічно-науковим комітетом, який залучає до участі принаймні один університет, університетський відділ, дослідницький центр.

3-5 травня 2018 року було визначено Національний дослідницький оперативний план 3 питань освіти дорослих. План передбачав реалізацію таких стратегічних дій, як: розширення спектру програм у галузі досліджень; вдосконалення обласних центрів освіти дорослих щодо 


\section{Інноватика у вихованні. Випуск 13.Том 2. 2021.}

надання послуг; сприяння зв'язку між навчальною ланкою першого рівня та навчальною ланкою другого рівня; сприяння розвитку та функціонуванню територіальних мереж для навчання впродовж життя.

Перехід до нової системи освіти дорослих супроводжується «національними системними заходами» для керівників, вчителів і адміністративно-технічного та допоміжного персоналу обласних центрів освіти дорослих. Генеральним директоратом шкільних систем та оцінки національної системи освіти 32015 р. реалізується План заходів щодо інновацій у галузі освіти дорослих (Il Piano di Attività per l'Innovazione dell'Istruzione degli Adulti (P.A.I.DE.I.A.)). План спрямовано на набуття дорослими управлінських, організаційних та дидактичних навичок, необхідних на різних рівнях, для заохочення застосування у професійному житті нових організаційних та дидактичних засобів (Ministero dell'Istruzione, 2021).

Діяльність, що проводиться обласними центрами освіти дорослих в рамках Плану заходів щодо інновацій в галузі освіти дорослих (P.A.I.DE.I.A.), спрямована на визначення необхідних умов для формування індивідуального навчального плану; розробку системних заходів, необхідних для зв'язку між навчальними ланками першого та другого рівнів; проведення дослідницьких, експериментальних заходів та впровадження $з$ метою розширення спектру освітніх пропозицій.

32017 року реалізується національний проєкт «EDUFINCPIA», який сприяє подоланню освітнього дефіциту дорослого населення у сфері фінансової освіти, а також передбачає розробку та забезпечення спеціальних навчальних підрозділів для дорослих, які навчаються в СРІА 3 метою надання їм можливості набути мінімальні навички, пов'язані 3 фінансовою освітою.

Освіта дорослих також охоплює освіту осіб, що перебувають у місцях позбавлення волі, ізоляторах тимчасового тримання. Організація освітньовиховного процесу спрямована на перевиховання ув'язненого 3 метою відновлення його соціального статусу та повернення до нормальних умов життя. Комплексна допомога ув'язненим та звільненим особам щодо визначення особистого плану життя та формування власної відповідальності перед собою сприяє їхній реінтеграції у суспільство та відновлення їхнього соціального статусу повноцінного члена суспільства, трудового колективу, що призводить до поповнення ресурсу на ринку праці працездатними громадянами.

Організація курсів у закладах профілактики та покарання, в центрах соціальної адаптації передбачає здійснення соціального патронажу щодо таких осіб, а також розробку нових організаційних методів та дидактичних засобів 3 врахуванням специфіки учасників освітньовиховного процесу. Впровадження інноваційних методик під час роботи із засудженими та звільненими особами передбачає введення у навчальні плани закладів освіти необхідних організаційних коректив щодо освітніх 


\section{Інноватика у вихованні. Випуск 13.Том 2. 2021.}

потреб дорослих у в’язниці, особливостей місць навчання та часу утримання.

Обласні центри освіти дорослих та школи можуть у межах своєї автономії укладати конкретні угоди, зокрема, про сприяння вдосконаленню кадрового складу, організацію навчально-виховних заходів, створення дидактичних лабораторій, поповнення бібліотечного фонду, а також інтеграцію та підтримку неповнолітніх навіть після звільнення 3 в'язниці. До розв'язання проблем долучаються недержавні організації, які є динамічними, мобільними, залучають благодійні кошти, сприяючи розвитку громадянського суспільства.

У 2015 році указом Міністерства освіти, університетів та досліджень було сформовано Національну систему регіональних кваліфікацій, що визначає механізм взаємного визнання міжрегіональних кваліфікацій; сертифікує та проводить стандартні системні процедури щодо ідентифікації та перевірки служб неформальної освіти та інформального навчання, а у січні 2018 року створено Національну рамку кваліфікацій як інструмент для опису та класифікацій, прописаних в рамках Національної системи сертифікації компетентностей, підписану указом Міністерства праці та соціальної політики (Decreto 8 gennaio, 2018).

Інноваційним аспектом нової системи освіти дорослих, яка допомагає реалізувати національну політику навчання впродовж життя, є підвищення культурного та професійного досвіду людини, починаючи 3 удосконалення особистого життєвого шляху. Підписання індивідуальної угоди (контракту) про навчання між дорослою людиною та керівником CPIA фактично дозволяє визнати офіційні, неформальні та інформальні знання та навички, якими оволодіє дорослий під час навчання.

Висновки і перспективи подальших розвідок. Таким чином, на основі теоретичного аналізу проблеми освіти дорослих у системі неперервної професійної освіти в Італійській Республіці, законодавчого регулювання освітньо-виховного процесу зроблено висновок, що навчання, яке проводять обласні центри освіти дорослих (CPIA), сприяє набуттю знань, навичок та компетентностей, які можна конкретно застосувати у повсякденному житті дорослого. Розвиток одержаних навичок дає змогу визначити мультиплікативний ефект, який впливає на громадянське та соціальне благополуччя, збільшуючи доступ до ринку праці. Взаємодія між ринком праці, системою освіти та навчання передбачає активну участь як державних, так i приватних суб'єктів. Державна система сертифікації навичок, узгоджена 3 міжнародними, національними та регіональними кодифікованими класифікаціями, а також Свропейською системою кваліфікацій (EQF), $\epsilon$ основним інструментом щодо підвищення рівня якості освіти дорослих.

Перспективи подальших досліджень вбачаємо у вивченні систем професійної орієнтації та програм професійної підтримки особистості на етапі самовизначення, що діють в європейських країнах. 


\section{СПИСОК ВИКОРИСТАНИХ ДЖЕРЕЛ}

European Communities: A Memorandum on Lifelong Learning, issued in 2000. (2000). URL: https://uil.unesco.org/document/european-communitiesmemorandum-lifelong-learning-issued-2000. [Дата звернення 03.05.21].

Recommendation on adult learning and education (2015). URL: https://unesdoc.unesco.org/ark:/48223/pf0000245119.page=3. [Дата звернення 03.05.21].

L'Istituto Nazionale di Documentazione, Innovazione e Ricerca Educativa (Indire).(2021). URL: https://j44cr3oz6c2ygz66ftc73v3loaadv7ofecxzh2qqi-www-indire. [Дата звернення 03.05.21].

Legge 92 del 2012. (2012). URL: https://www.miur.gov.it/istruzionedegli-adulti. [Дата звернення 04.05.21].

Simkins T. (1977). Non-Formal Education and Development. Some critical issues. Manchester: Department of Adult and Higher Education, University of Manchester, 1977. 77 p.

Ministero dell'Istruzione. Ministero dell'Università e della Ricerca (2021). URL: https://oe24nldmbmdqc7b7zib4uclj5a-adv7ofecxzh2qqi-www-miur-gov [Дата звернення 03.05.21].

Risoluzione del Consiglio Europeo 2011/c 372/01 pubblicata sulla GUCE del 20 dicembre 2011. (2011). URL: https://www.miur.gov.it/istruzione-degliadulti._Дата звернення 05.05.21].

Decreto 8 gennaio 2018. (2018). Istituzione del Quadro nazionale delle qualificazioni rilasciate nell'ambito del Sistema nazionale di certificazione delle competenze di cui al decreto legislativo 16 gennaio 2013, n. URL: http://www.gazzettaufficiale.it/eli/id/2018/01/ 25 / 18A00411 / sg. [Дата звернення 04.05.21].

\section{REFERENCES}

European Communities: A Memorandum on Lifelong Learning, issued in 2000. (2000). URL: https://uil.unesco.org/document/european-communitiesmemorandum-lifelong-learning-issued-2000 [Data zvernennia 03.05.21]. [Дата звернення 03.05.21р.]. [in English].

Recommendation on adult learning and education (2015). URL: https://unesdoc.unesco.org/ark:/48223/pf0000245119.page=3. [Data zvernennia 03.05.21]. [in Italian].

L'Istituto Nazionale di Documentazione, Innovazione e Ricerca Educativa (Indire).(2021). URL: https://j44cr3oz6c2ygz66ftc73v3loaadv7 ofecxzh2qqi-www-indire. [Data zvernennia 03.05.21]. [in Italian].

Legge 92 del 2012. (2012). URL: https://www.miur.gov.it/istruzionedegli-adulti. [Data zvernennia 03.05.21]. [in Italian].

Simkins T. (1977). Non-Formal Education and Development. Some critical issues. Manchester: Department of Adult and Higher Education, University of Manchester, 1977. 77 p. [in English]. 


\title{
Інноватика у вихованні. Випуск 13.Том 2. 2021.
}

Ministero dell'Istruzione. Ministero dell'Università e della Ricerca (2021). URL: https://oe24nldmbmdqc7b7zib4uclj5a-adv7ofecxzh2qqi-www-miur-gov [Data zvernennia 03.05.21]. [in Italian].

Risoluzione del Consiglio Europeo 2011/c 372/01 pubblicata sulla GUCE del 20 dicembre 2011. (2011). URL: https://www.miur.gov.it/istruzione-degliadulti._[Data zvernennia 03.05.21]. [in Italian].

Decreto 8 gennaio 2018. (2018). Istituzione del Quadro nazionale delle qualificazioni rilasciate nell'ambito del Sistema nazionale di certificazione delle competenze di cui al decreto legislativo 16 gennaio 2013, n. URL: http://www.gazzettaufficiale.it/eli/id/2018/01/ 25 / 18A00411 / sg [Data zvernennia 04.05.21]. [in Italian].

\section{ADULT EDUCATION IN THE CONTEXT OF MODERN CONTINUOUS EDUCATION IN THE ITALIAN REPUBLIC: TRAINING AND UPBRINGING}

\author{
Tatiana Krystopchuk \\ Doctor of Sciences (in Pedagogy), Associate Professor, \\ Professor at the Department of Theory and Methods of Education \\ Rivne State University for the Humanities, \\ Rivne, Ukrain \\ ORCID: 0000-0002-0104-9901 \\ e-mail: krystopchuk@ukr.net
}

\begin{abstract}
The article analyzes the initial conceptual issues for the development of adult education, reflected in the legal framework of the Italian Republic. Adult education is characterized as a set of educational processes of formal, non-formal education and informal learning. The main content's components of adult education in the context of modern continuing education are identified: basic learning skills development; vocational training and development; general cultural self-improvement, forming skills of active civil position. Forms of realization of adult education are determined: special, for which a special time and place is allocated (seminars, organizational and active games); situational, implemented in the course of innovative activities of a specialist through the processes of reflection; relevant when the educational result of any activity becomes a new means of their own activity. Peculiarities of non-formal adult education programs are analyzed. It is noted that adult education is organized in Permanent Territorial Centers (PTC) and evening courses conducted by higher education institutions. It is emphasized that the development of adult education is facilitated by the Regional Centers of Adult Education (RCAE) and the Regional Centers of Research, Experiments and Development (RCRE \& D). The structure of Regional Centers for Adult Education (RCAE) is determined: administrative unit; didactic unit; training unit. It is established that the National System of Regional Qualifications determines the mechanism of mutual recognition of interregional qualifications;
\end{abstract}




\section{Інноватика у вихованні. Випуск 13.Том 2. 2021.}

certifies and conducts standard system procedures for the identification and verification of non-formal education and information learning services. It is emphasized that adult education covers the education of persons in places of imprisonment and preventive institutions. The organization of the educational process in such institutions is seen as a comprehensive assistance to prisoners and dismissed persons in determining their personal life plan and forming their own responsibility, facilitating their reintegration into society and restoring their social status as a full member of society. It is highlighted that training in adult education centers contributes to the acquisition of competencies by increasing access to the labor market.

Keywords: adult education; legislative regulation of adult education; the content of adult education; forms of adult education implementation; Regional Centers of Adult Education; Regional Centers of Research, Experiments and Development.

Стаття надійшла до редакиії 05.05.2021p. 